OPEN ACCESS

Edited by:

Silvia Franzellitti,

University of Bologna, Italy

Reviewed by:

Anna Palumbo

Stazione Zoologica Anton Dohrn, Italy

Teresa Balbi,

University of Genoa, Italy

*Correspondence:

Jin-Long Yang

jlyang@shou.edu.cn

Xiao Liang

x-liang@shou.edu.cn

${ }^{t}$ These authors have contributed

equally to this work

Specialty section:

This article was submitted to

Aquatic Physiology,

a section of the journal

Frontiers in Marine Science

Received: 12 August 2019

Accepted: 27 April 2020

Published: 04 June 2020

Citation:

Zhu Y-T, Zhang Y, Liu Y-Z, Li Y-F, Yoshida A, Osatomi $K$, Yang $J-L$ and Liang X (2020) Nitric Oxide Negatively Regulates Larval Metamorphosis in Hard-Shelled Mussel (Mytilus coruscus). Front. Mar. Sci. 7:356

doi: 10.3389/fmars.2020.00356

\section{Nitric Oxide Negatively Regulates Larval Metamorphosis in Hard-Shelled Mussel (Mytilus coruscus)}

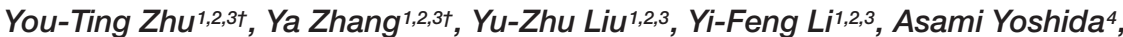 \\ Kiyoshi Osatomi ${ }^{4}$, Jin-Long Yang ${ }^{1,2,3 *}$ and Xiao Liang ${ }^{1,2,3 *}$
}

1 International Research Center for Marine Biosciences, Ministry of Science and Technology, Shanghai Ocean University, Shanghai, China, ${ }^{2}$ Key Laboratory of Exploration and Utilization of Aquatic Genetic Resources, Ministry of Education, Shanghai Ocean University, Shanghai, China, ${ }^{3}$ National Demonstration Center for Experimental Fisheries Science Education, Shanghai Ocean University, Shanghai, China, ${ }^{4}$ Graduate School of Fisheries and Environmental Sciences, Nagasaki University, Nagasaki, Japan

Marine invertebrates undergo distinct life cycles and development processes, and some undergo a metamorphic transition from pelagic larvae to benthic juvenile. Previous studies have shown that the second messenger nitric oxide (NO) plays important roles in regulating larval metamorphosis in marine invertebrates. However, this regulatory function is not conserved. Herein, we investigated the regulatory role of $\mathrm{NO}$ in larval metamorphosis in hard-shelled mussel (Mytilus coruscus). Pharmacological experiments revealed that after exposure to nitric oxide synthase (NOS) inhibitors, the larval metamorphosis rate was increased significantly. By contrast, exposure to $\mathrm{NO}$ donors significantly reduced the larval metamorphosis rate. To further investigate the function of $\mathrm{NO}$ in metamorphosis, we cloned the NOS cDNA sequence from M. coruscus (McNOS), analyzed amino acid sequences of McNOS from different species, and measured McNOS mRNA temporal expression alongside the molecular chaperone heat shock protein 90 (HSP90) in different larval stages. The results showed that NOS proteins share a highly conserved domain sequence in different species, even in invertebrates and vertebrates, but their classification among invertebrates and vertebrates is not the same. Except for the umbo veliger stage, McNOS mRNA was expressed at low levels in pediveliger larval and postlarvae stage, indicating a potential inhibitory function for NO in larval metamorphosis. Meanwhile, HSP90 mRNA expression was correspondingly high in the umbo veliger stage and lower in the pediveliger larval and postlarvae stage, indicating potential functional synergism. Interestingly, McNOS enzyme activity in different larval stages was inconsistent with its mRNA expression. Metamorphosis assays of pharmacological treatments combined with McNOS and HSP9O gene expression and NOS enzyme activity analyses indicated that NO acts as a suppressor to regulate metamorphosis in $M$. coruscus, regardless of whether $\mathrm{NO}$ is endogenous or exogenous.

Keywords: nitric oxide, negative regulator, metamorphosis, hard-shelled Mussel, Mytilus coruscus, NOS, HSP90 


\section{INTRODUCTION}

Marine invertebrates are major members of coastal and marine benthic communities, and they are characterized by indirect development with a dispersive larval stage in their life histories (Qian, 1999). Their biphasic life cycles include a planktonic larval phase and a benthic adult phase (Strathmann, 1993; Qian, 1999; Hadfield et al., 2001). In the early stages of development, larvae spend time developing among plankton before settling and undergoing metamorphosis (Qian, 1999). Competent larvae can settle and metamorphose only when environmental conditions are suitable. In most species, larval settlement and metamorphosis are determined by exogenous factors such as physical, biological, or chemical parameters related to the substratum, derived from conspecific or congeneric individuals, biofilms, sympatric species, food, or habitats, as well as endogenous factors such as the neurotransmitters (Qian, 1999; Joyce and Vogeler, 2018).

Invertebrate larvae can recognize and respond to appropriate cues, which is crucial for choosing suitable sites for survival, growth, and reproduction during a settled life (Rodríguez et al., 1993; Ueda and Degnan, 2014). Receptors on sensory organs can receive signals from appropriate environmentderived ligands such as biological cues from bacterial biofilms and conspecifics, chemical cues including ion concentrations, ammonia, and neuroactive compounds such as epinephrine (EPI), 5-hydroxytryptamine, L-3,4-dihydroxyphenylalanine, $\gamma$-aminobutyric acid, acetylcholine, and isobutyl-methylxanthine (Beiras and Widdows, 1995; García-Lavandeira et al., 2005; Teh et al., 2012; Grant et al., 2013; Mesías-Gansbiller et al., 2013; Joyce and Vogeler, 2018). These signals activate conserved intercellular signaling pathways and thereby regulate settlement and metamorphosis of larvae (Hadfield et al., 2000).

The nitric oxide (NO) signaling pathway is highly conserved in invertebrates, acts as a mediator in multiple cell signaling pathways, and regulates a wide spectrum of biological functions involved in neurotransmission, host defenses, blood flow, and muscle relaxation in mammals (Bruckdorfer, 2005). Endogenous $\mathrm{NO}$ is a highly conserved second messenger molecule mainly generated by nitric oxide synthase (NOS), which converts the substrate L-arginine to L-citrulline and NO (Stuehr, 2004). Heat shock protein 90 (HSP90), a chaperone that assists the folding of various proteins and stabilizes them against heat stress and other cellular stresses (Lindquist and Craig, 1988; Borkovich et al., 1989; Young et al., 2001), is required to maintain normal NOS enzymatic activity (García-Cardeña et al., 1998). HSP90 acts as an allosteric modulator by associating with and activating NOS, thereby stimulating NO production (García-Cardeña et al., 1998; Bender et al., 1999; Yoshida and Xia, 2003). Inside the cell, NO can stimulate cGMP production by binding to soluble guanylyl cyclase (Lucas et al., 2000) and participates in the formation of an iron-nitrosyl-heme complex by binding to the regulatory domain of heme groups, and this is required for GC activation and cGMP production (Lucas et al., 2000; Bruckdorfer, 2005; Hong et al., 2008).

Notably, the important role of NO in larval settlement and metamorphosis is conserved in numerous marine invertebrates
(Colasanti and Venturini, 1998; Palumbo, 2005). Recent evidence indicates that NO can inhibit the initiation of larval settlement and metamorphosis in various marine organisms belonging to different phyla, including bryozoans (Yang et al., 2018), mollusks (Froggett and Leise, 1999; Pechenik et al., 2007; Bishop et al., 2008; Romero et al., 2012), annelida (Biggers et al., 2012), arthropods (Zhang et al., 2012, 2015), echinoderms (Bishop and Brandhorst, 2001), and tunicates (Bishop et al., 2001; Comes et al., 2007). Mechanistic research revealed that NO modulates larval settlement by regulating tail regression through caspase-dependent apoptosis and ERK signaling in Ciona intestinalis, and muscle locomotion and molting via myosin and cuticular protein repression in Amphibalanus amphitrite (Comes et al., 2007; Castellano et al., 2014; Zhang et al., 2015). In addition, NO was found to act as a positive regulator of metamorphosis in the ascidians Herdmania momus and $C$. intestinalis, and the abalone Haliotis asinina (Ercolesi et al., 2012; Ueda and Degnan, 2013, 2014; Castellano et al., 2014). However, the differences in the action of NO as positive or negative regulator of metamorphosis require further investigation.

The hard-shelled mussel (Mytilus coruscus) inhabits the temperate zone of coastal waters in East Asia and is an important commercial marine bivalve and fouling organism in the East China Sea (Wang et al., 2012). In recent years, evidence has shown that larval metamorphosis is regulated by $\mathrm{NO}$ in some marine invertebrates, it is dependent on HSP90, and it involves both positive and negative regulation. However, the regulatory roles of $\mathrm{NO}$ in $M$. coruscus remain unknown. Herein, we investigated the regulatory function of NO in $M$. coruscus metamorphosis by examining the pharmacological effects of NOS inhibitors and NO donors on the initiation of larval metamorphosis. Additionally, to further understand the role of NO in larval metamorphosis, the full-length cDNA of the McNOS gene was characterized, and McNOS and HSP90 gene expression were investigated in larvae at different developmental stages and in different tissues using quantitative reverse transcriptase-polymerase chain reaction (RT-qPCR).

\section{MATERIALS AND METHODS}

\section{Spawning and Larval Culture}

Adult mussels ( $M$. coruscus) were obtained from Gouqi Island in China $\left(30^{\circ} 72^{\prime} \mathrm{N}, 122^{\circ} 77^{\prime} \mathrm{E}\right)$ and immediately transferred to the laboratory on the same day. Mussels were cleaned and kept in a $10-\mathrm{L}$ polycarbonate tank containing filtered seawater (FSW) passed through a $1.2-\mu \mathrm{m}$ acetate-fiber filter, maintained at $21^{\circ} \mathrm{C}$, and fed a mixed diet of Platymonas helgolandica and Isochrysis zhanjiangensis every day. Adult mussels were sacrificed, and mantle, adductor muscle, gill, foot, digestive gland, and male and female gonads were harvested and immediately frozen at $-80^{\circ} \mathrm{C}$.

Spawning was induced in the laboratory following a previously described method (Yang et al., 2008) with slight modifications. In brief, mussels were reared in $10-\mathrm{L}$ polycarbonate tanks at 


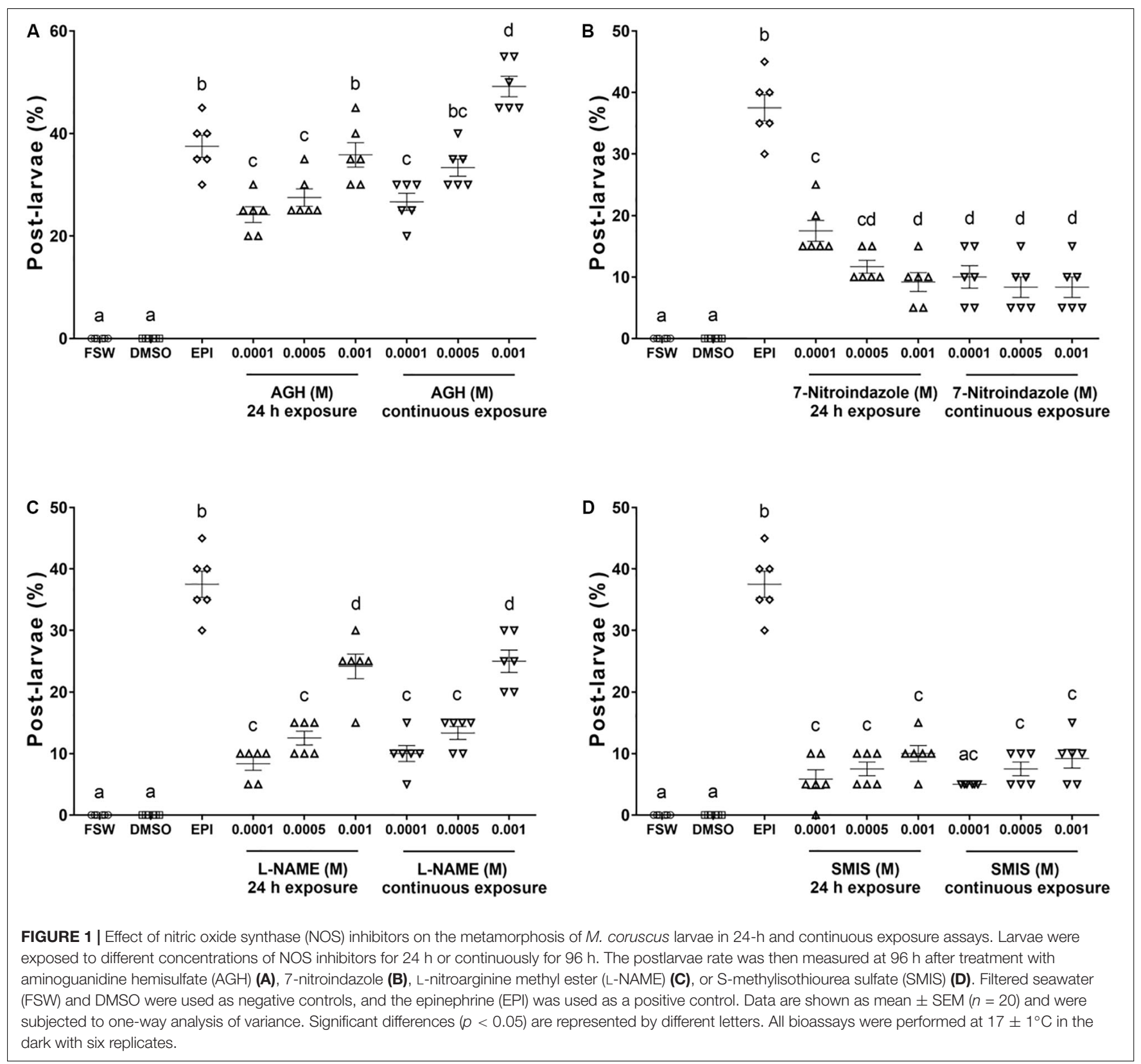

$21^{\circ} \mathrm{C}$ after storing on ice overnight. Mussels were separated and transferred to 2-L glass beakers filled with FSW to initiate spawning. Fertilization was conducted by gently mixing eggs and sperm suspensions in FSW and incubating for $20 \mathrm{~min}$. Fertilized eggs were kept at $18^{\circ} \mathrm{C}$ in FSW after removing excess sperm by washing with FSW on a nylon plankton net $(20-\mu \mathrm{m}$ mesh size). After 2 days, swimming larvae were fed $P$. helgolandica and $I$. zhanjiangensis at a density of $5 \times 10^{4}$ cells/mL every day. Mussel larvae at different developmental stages (trochophore, D-shaped, umbo, pediveliger, and postlarvae) were isolated, frozen in liquid nitrogen, and stored at $-80^{\circ} \mathrm{C}$. Pediveliger larvae were used in metamorphosis experiments. All animal handling procedures were approved by the Institutional Animal Care and Use Committee of Shanghai Ocean University.

\section{Metamorphosis Assays of Pharmacological Treatments}

Chemicals used for NO functional verification, including NOS inhibitors aminoguanidine hemisulfate (AGH), 7nitroindazole, L-NG-nitroarginine methyl ester (L-NAME), S-methylisothiourea sulfate (SMIS), and NO donors S-nitroso$N$-acetyl-DL-penicillamine (SNAP), L-arginine, and sodium nitroprusside (SNP) were all from Sigma-Aldrich (St. Louis, MO, United States). Stock solutions of all chemicals were prepared as explained in the relevant manuals $(\mathrm{AGH}$, $10^{-3} \mathrm{M} ;$ 7-nitroindazole, $10^{-3} \mathrm{M} ;$ L-NAME, $10^{-3} \mathrm{M}$; SMIS, $10^{-2} \mathrm{M}$; SNAP, $10^{-3} \mathrm{M}$; L-arginine, $10^{-3} \mathrm{M}$; SNP, $10^{-3} \mathrm{M}$ ) using distilled water or $1 \mathrm{M} \mathrm{HCl}$ and diluted to 
the desired final concentrations (see the information in the figure) with autoclaved FSW (pH 7.8-8.2). All stock solutions and test chemical compounds were prepared and used within $24 \mathrm{~h}$.

The method of larval metamorphosis detection was performed as described previously (Yang et al., 2013). Bioassays were conducted in 60-mm Petri dishes containing 20 pediveliger larvae and $20 \mathrm{~mL}$ of test solution. Different concentrations of NOS inhibitors were assessed in a 24-h or continuous exposure period. In 24-h exposure tests, pediveliger larvae were first exposed to four different concentrations of NOS inhibitors $\left(\mathrm{AGH}=10^{-4}, 5 \times 10^{-4}, 10^{-3} \mathrm{M}\right.$; 7-nitroindazole $=5 \times 10^{-4}$, $10^{-3}, 2 \times 10^{-3} \mathrm{M} ; \mathrm{L}-\mathrm{NAME}=10^{-5}, 10^{-4}, 10^{-3} \mathrm{M}$; SMIS $\left.=5 \times 10^{-5}, 2.5 \times 10^{-5}, 5 \times 10^{-4} \mathrm{M}\right)$. After $24 \mathrm{~h}$, tested larvae were washed three times with FSW, and all test solution was replaced with $20 \mathrm{~mL}$ FSW. The postlarvae rate was measured at $96 \mathrm{~h}$ after exposure. In continuous exposure tests, pediveliger larvae were exposed to four different concentrations of NOS inhibitors (concentrations were the same as for 24-h exposure tests) for $96 \mathrm{~h}$, and the postlarvae rate was measured. To further verify the effects of $\mathrm{NO}$ on larval metamorphosis regulation, 20 pediveliger larvae were exposed to different concentrations of NO donors (SNAP $=10^{-6}, 10^{-5}$, $10^{-4} \mathrm{M}$; L-arginine $=10^{-5}, 10^{-4}, 10^{-3} \mathrm{M}, \mathrm{SNP}=10^{-5}$, $10^{-4}, 10^{-3} \mathrm{M}$ ) for $15 \mathrm{~min}$ and then to the NOS inhibitor AGH (final concentration $=10^{-4} \mathrm{~mol} / \mathrm{L}$ ) for $24 \mathrm{~h}$ to inhibit the production of endogenous NO. The solution was then replaced with $20 \mathrm{~mL}$ FSW after three washes with FSW. The postlarvae rate was measured at $96 \mathrm{~h}$ after NO donor treatment. Dead larvae were also recorded during the experiment. EPI $\left(10^{-4} \mathrm{M}\right)$ was used as a positive control, and dimethyl sulfoxide (DMSO) and FSW (blank) were used as negative controls. All bioassays were performed at $17 \pm 1^{\circ} \mathrm{C}$ in the dark with six replicates.

\section{Total RNA Extraction and First-Strand cDNA Synthesis}

Total RNA from mussels and larvae was extracted using TRIzol reagent (Invitrogen, Carlsbad, CA, United States) according to the manufacturer's protocol and quantified using a NanoDrop One instrument (Thermo Scientific, Waltham, MA, United States). RNA quality was assessed by $1 \%$ agarose gel electrophoresis. For cloning the full-length NOS cDNA, $5 \mu \mathrm{g}$ of total RNA from mussel mantle was extracted and reverse-transcribed using a SMARTer RACE 5'/3' Kit (Clontech, Mountain View, CA, United States) following the instructions of the manufacturer. For gene expression profiling of larvae and different tissues, $1000 \mathrm{ng}$ of total RNA was reverse-transcribed using a Transcriptor first-strand cDNA synthesis kit (Roche, Basel, Switzerland) following the manufacturer's instructions.

\section{Cloning of the McNOS Full-Length cDNA}

Gene-specific primers (NOS-F1 and NOS-R1) for 5'- and 3'-RACE were designed based on the $M$. coruscus NOSexpressed sequence tag and synthesized by Sangon Biotech
TABLE 1 | Primers used for gene cloning and expression analysis.

\begin{tabular}{lll}
\hline Primer name & Nucleotide sequence (5' - 3') & Experiment \\
\hline NOS-3' RACE-F1 & CGGTCATTGGTGATCCAGCAGCTAT & 3' RACE \\
NOS-3' RACE-F2 & GGATGGTATATGGGGACTGAAATT & 3' RACE \\
NOS-5' RACE-R1 & CGGCTGTTGTAGCCAGCATACATA & 5' RACE \\
NOS-5' RACE-R2 & TCCAGTCCACCACAATCAAACAACA & 5' RACE \\
NOS-qPCR-F & GAAGTTCAAATAAAGCATCCAAAAT & RT-qPCR \\
NOS-qPCR-R & GTGGTGGTCCATTATTGAGCTCCT & RT-qPCR \\
HSP90-qPCR-F & TTACCGTCAAAACAGTAACAGGTG & RT-qPCR \\
HSP90-qPCR-R & AGGATAACCAATGAACTGACTGTGT & RT-qPCR \\
EF-1 $\alpha-F$ & CACCACGAGTCTCTCCCTGA & RT-qPCR \\
EF-1 $\alpha-R$ & GCTGTCACCACAGACCATTCC & RT-qPCR \\
\hline
\end{tabular}

(Shanghai, China; Table 1). Both 5'-and 3'-RACE were performed by touchdown PCR using a SMARTer RACE 5'/3' Kit and thermal cycling with five initial cycles of denaturation at $94^{\circ} \mathrm{C}$ for $30 \mathrm{~s}$, annealing at $68^{\circ} \mathrm{C}$ for $30 \mathrm{~s}$, and elongation at $72^{\circ} \mathrm{C}$ for $2 \mathrm{~min}$, followed by five cycles of denaturation at $94^{\circ} \mathrm{C}$ for $30 \mathrm{~s}$, annealing at $66^{\circ} \mathrm{C}$ for $30 \mathrm{~s}$, and elongation at $72^{\circ} \mathrm{C}$ for $2 \mathrm{~min}$, and 25 cycles at $94^{\circ} \mathrm{C}$ for $30 \mathrm{~s}, 66^{\circ} \mathrm{C}$ for $30 \mathrm{~s}$, and $72^{\circ} \mathrm{C}$ for 2 min. Polymerase chain reaction products were separated by $1.2 \%$ agarose gel electrophoresis, and the specific band was retrieved using an E.Z.N.A. Gel Extraction Kit (Omega, Norcross, GA, United States) and ligated into the pMD19$\mathrm{T}$ vector (TaKaRa, Dalian, China) for sequencing. Successfully transformed recombinant colonies were selected and confirmed by sequencing (Sangon Biotech).

\section{Analysis of NOS Nucleotide and Amino Acid Sequences}

The obtained full-length McNOS cDNA sequence was validated using BLAST ${ }^{1}$. The open reading frame (ORF) was predicted using ORF Finder ${ }^{2}$, and signal peptides and signature domains were identified using the SignalP 4.1 server $^{3}$ and the SMART $\mathrm{Tool}^{4}$, respectively. The molecular weight and isoelectric point (pI) of the protein were predicted by Compute $\mathrm{pI} / \mathrm{Mw}^{5}$. Potential $\mathrm{N}$-glycosylation sites were predicted using the NetNGlyc 1.0 Server 6 . The similarity and identity of protein sequences were calculated using BLAST. Multiple sequence alignment was performed with Clustal Omega ${ }^{7}$. A maximum likelihood (ML) phylogenetic tree was constructed using PhyML with 100 bootstrap replicates within the Smart Model Selection tool ${ }^{8}$.

\section{Quantitative Real-Time PCR Analysis}

Total RNA extracted from different larval developmental stages (trochophore, D-shaped, umbo, pediveliger larvae, and

\footnotetext{
${ }^{1}$ https://blast.ncbi.nlm.nih.gov/Blast.cgi

${ }^{2}$ http://www.ncbi.nlm.nih.gov/gorf/gorf.html

${ }^{3}$ http://www.cbs.dtu.dk/services/SignalP/

${ }^{4} \mathrm{http}: / /$ smart.embl-heidelberg.de/

${ }^{5}$ http://www.expasy.ch/

${ }^{6}$ http://www.cbs.dtu.dk/services/NetNGlyc/

${ }^{7}$ https://www.ebi.ac.uk/Tools/msa/clustalo/

${ }^{8}$ http://www.atgc-montpellier.fr/phyml/
} 


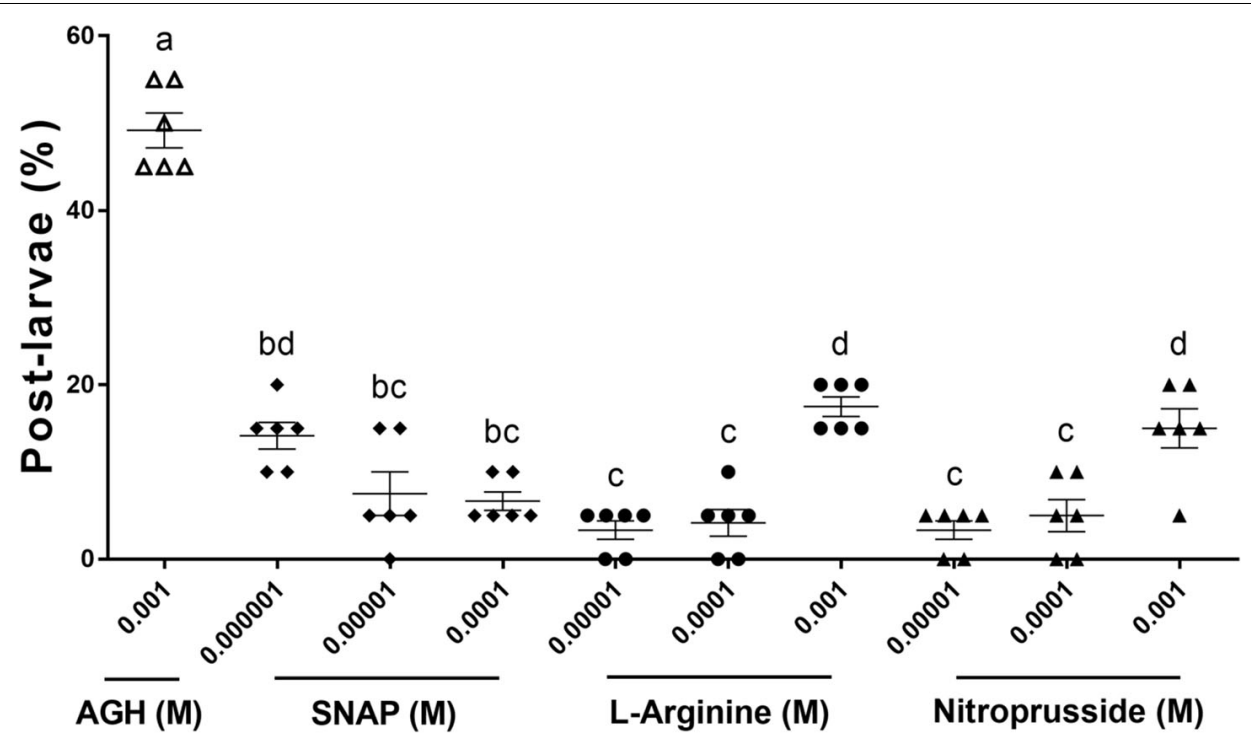

FIGURE 2 | Effect of NO donors on the metamorphosis of M. coruscus larvae. Larvae were exposed to NO donors S-nitroso-N-acetyl-DL-penicillamine (SNAP) (A), L-arginine (B), and sodium nitroprusside (SNP) (C) for $15 \mathrm{~min}$ and then inhibited by AGH for $24 \mathrm{~h}$, and the metamorphosis rate of larvae was measured at $96 \mathrm{~h}$ posttreatment with NO donors. Data are shown as mean \pm SEM $(n=20)$, and bars with different letters are significantly different. All bioassays were performed at $17 \pm 1^{\circ} \mathrm{C}$ in the dark with six replicates.

postlarvae) and different tissues were reverse-transcribed into first-strand cDNA as described above. The M. coruscus elongation factor $1 \alpha(E F 1-\alpha)$ gene was used as a reference for normalization to estimate relative gene expression levels. Primers designed for RT-qPCR analysis are listed in Table 1. Five biological replicates were used for RT-qPCR, and each reaction was performed in triplicate on a LightCycler 96 System (Roche). Relative expression levels were calculated using the $2^{-\Delta \Delta \mathrm{Ct}}$ comparative CT method (Livak and Schmittgen, 2001).

Each RT-qPCR experiment $(10 \mu \mathrm{L})$ contained $5 \mu \mathrm{L}$ of $2 \times$ FastStart Essential DNA Green Master (Roche), $0.3 \mu \mathrm{L}$ of specific forward and reverse primers (final concentration $300 \mathrm{nM}$ ), $3.4 \mu \mathrm{L}$ of deionized water, and $1 \mu \mathrm{L}$ of template cDNA. The RT-qPCR amplification protocol involved an initial denaturation at $95^{\circ} \mathrm{C}$ for $10 \mathrm{~min}$, followed by 45 cycles at $95^{\circ} \mathrm{C}$ for $10 \mathrm{~s}, 58^{\circ} \mathrm{C}$ for $10 \mathrm{~s}$, and $72^{\circ} \mathrm{C}$ for $10 \mathrm{~s}$. Melting curve analysis with a temperature gradient of $0.5^{\circ} \mathrm{C} / \mathrm{s}$ from 65 to $95^{\circ} \mathrm{C}$ was conducted to confirm that the amplified products were specific. The efficiency of RT-qPCR experiments varied between 90 and $105 \%$, with $R^{2} \geq 0.99$. For analysis of each gene, a standard curve relating the initial template quantity and the amplification cycle was performed using serial dilutions. The relative abundance of each transcript based on the standard curve was used to calculate the copy number.

\section{NOS Protein Activity Detection}

Larvae at different developmental stages were weighed, a fourfold volume of protein lysis buffer (10 mM TRIS, 1\% Triton X-100, $5 \%$ protease inhibitor cocktail) was added, and the homogenate was incubated on ice for $30 \mathrm{~s}$. After centrifuging at $10,000 \times g$ for $30 \mathrm{~min}$ at $4^{\circ} \mathrm{C}$, the supernatant was collected as soluble protein and tested using an RC DCTM Protein Assay Kit II
(Bio-Rad, Hercules, CA, United States). The total NOS activity was spectrophotometrically measured with the NOS colorimetric assay kit (A014-2; Nanjing Jiancheng Bioengineering Institute, Nanjing, China) based on its catalytic ability to convert Larginine into citrulline and $\mathrm{NO}$. NO was oxidized to nitrite $\left(\mathrm{NO}^{2-}\right)$ and nitrate $\left(\mathrm{NO}^{3-}\right)$. The $\mathrm{NO}^{3-}$ was converted to $\mathrm{NO}^{2-}$ utilizing nitrate reductase. Then, the Griess reagent was used to convert all the $\mathrm{NO}^{2-}$ into the color compound. According to the instruction, $100 \mu \mathrm{L}$ homogenate from different developmental stages larvae, $200 \mu \mathrm{L}$ substrate buffer, $10 \mu \mathrm{L}$ accelerant, and $100 \mu \mathrm{L}$ color developing agent were mixed and incubated at $37^{\circ} \mathrm{C}$ for $15 \mathrm{~min}$. The $100 \mu \mathrm{L}$ transparent agent and $2000 \mu \mathrm{L}$ stop solution were then added to the mixture, and the light absorption value of the mixture was determined by $530-\mathrm{nm}$ wavelength (the instrument was blanked with double distilled water). One unit of NOS activity was defined as the amount that catalyzed the formation of $1 \mathrm{nmol}$ of $\mathrm{NO}$ from arginine per minute at $37^{\circ} \mathrm{C}$. Five biological replicates were included for each sample, and enzyme activity is represented as units per milligram of protein.

\section{Statistical Analysis}

Relative mRNA levels are expressed as mean \pm standard error of the mean (SEM) for five individual mussel samples $(n=5)$. Each experiment was repeated at least twice. Statistical analysis was conducted using one-way analysis of variance followed by Student $t$-tests for comparison between two groups. Data on larval metamorphosis were arcsine-transformed before statistical analysis. Data for testing NOS inhibitor and donor effects were analyzed using Kruskal-Wallis tests followed by Steel and control tests. All statistical analyses were performed using Statistical Product and Service Solutions 15.0 (SPSS Inc., Chicago, 
IL, United States). Differences were considered statistically significant at $p<0.05$.

\section{RESULTS}

\section{NOS Inhibitors Upregulate Metamorphosis in M. coruscus Larvae}

Nitric oxide synthase inhibitors were used to test the metamorphosis regulation function of $\mathrm{NO}$ in $M$. coruscus larvae. In 24-h exposure trials, compared with negative controls (FSW and DMSO), the metamorphosis rate of larvae was significantly increased after exposure to all tested NOS inhibitors $(p<0.05$, Figure 1). After exposure to $0.001 \mathrm{mM} \mathrm{AGH}$ or L-NAME, the metamorphosis rate of larvae was increased by 36 and $24 \%$, respectively (Figures 1A,C). This significant increase was similar for AGH and EPI. In addition, even though the metamorphosis rate of larvae declined with increasing concentrations of 7-nitroindazole, it was still significantly higher than controls $(p<0.001)$ and peaked at $18 \%$ at $5 \times 10^{-4} \mathrm{mM}$ (Figure 1B). The metamorphosis rate of larvae did not change upon exposure to different concentrations of SMIS.

Similar to 24-h exposure trials, the metamorphosis rate of larvae was also raised with increasing exposure to $0.001 \mathrm{mM}$ AGH and L-NAME in continuous ( $96 \mathrm{~h}$ ) experiments and peaked at 49 and 25\%, respectively (Figures $\mathbf{1 A}, \mathbf{C}$ ). The metamorphosis rate of larvae was not altered by different concentrations of 7nitroindazole or SMIS (Figures 1B,D). Unlike the 24-h exposure tests, when the exposure time was extended, the metamorphosis rate of larvae following AGH exposure was significantly higher than with EPI $(p<0.0001$, Figure 1A). All NOS inhibitors significantly increased the larval metamorphosis rate compared with the controls (FSW and DMSO), especially AGH and LNAME, for which induction was increased significantly with increasing concentration $(p<0.05)$.

\section{NO Donors Suppress Metamorphosis in \\ M. coruscus Larvae}

Treatment of larvae with different concentrations of SNAP and nitroprusside, the two most well-studied NO donors, and $\mathrm{L}$-arginine (the endogenous substrate for NOS) (Grossi and D’Angelo, 2005; Ueda and Degnan, 2013; Yang et al., 2018), strongly inhibited larval metamorphosis after AGH treatment $(p<0.0001$, Figure 2). The larval metamorphosis rate was 3, 4, and 18 and 3,5 , and $15 \%$ after treatment with $1 \times 10^{-5}, 1 \times 10^{-4}$, or $1 \times 10^{-3} \mathrm{mM} \mathrm{L}$-arginine and nitroprusside treatment, respectively. However, unlike with these two NO donors, the larval metamorphosis rate was inhibited upon exposure to an increasing concentration of SNAP. The larvae metamorphosis rate was 14,8 , and $7 \%$ after exposure to $1 \times 10^{-6}, 1 \times 10^{-5}$, and $1 \times 10^{-4} \mathrm{mM}$ SNAP, respectively (Figure 2).

\section{Characterization of the Full-Length M. coruscus NOS cDNA}

The 5091-bp McNOS cDNA (GenBank ID: MN153299) includes a 4497-bp ORF with a 116-bp 5' untranslated region (UTR)

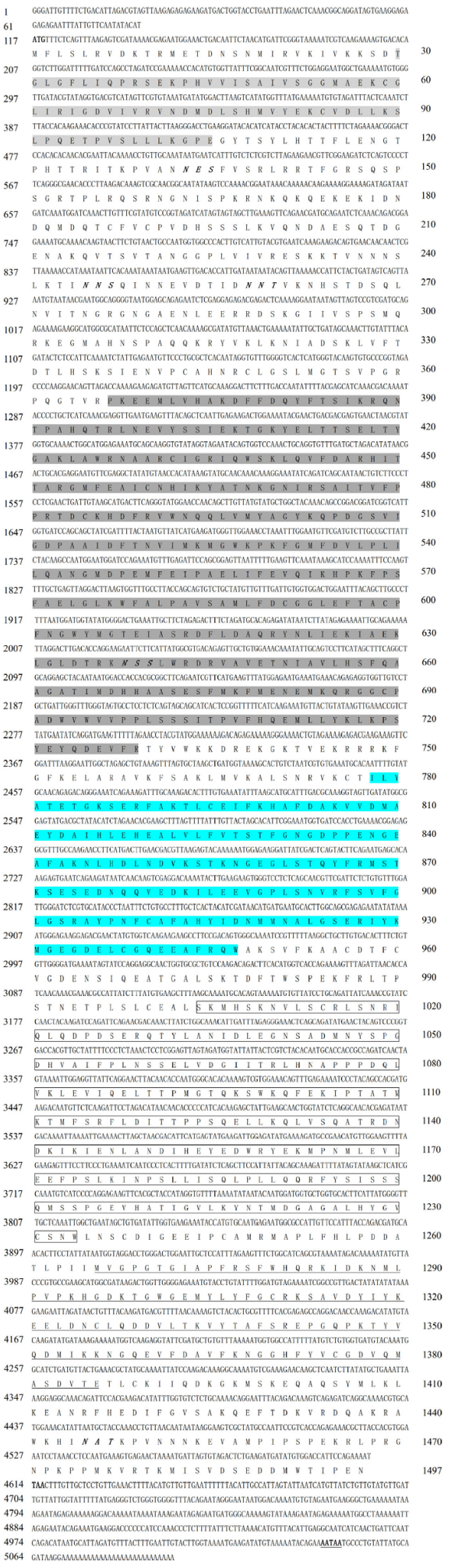

FIGURE 3 | Nucleotide and deduced amino acid sequences of McNOS. Start and stop codons are in bold, and the poly(A) tail is bold and underlined. The PDZ domain is shaded light gray. The NO synthase domain is shaded dark gray. The flavodoxin 1 domain is shaded blue. The FAD binding 1 domain is boxed. The NAD binding 1 domain is underlined. The five potential $\mathrm{N}$-glycosylation sites (NXT) are bold and italicized. 


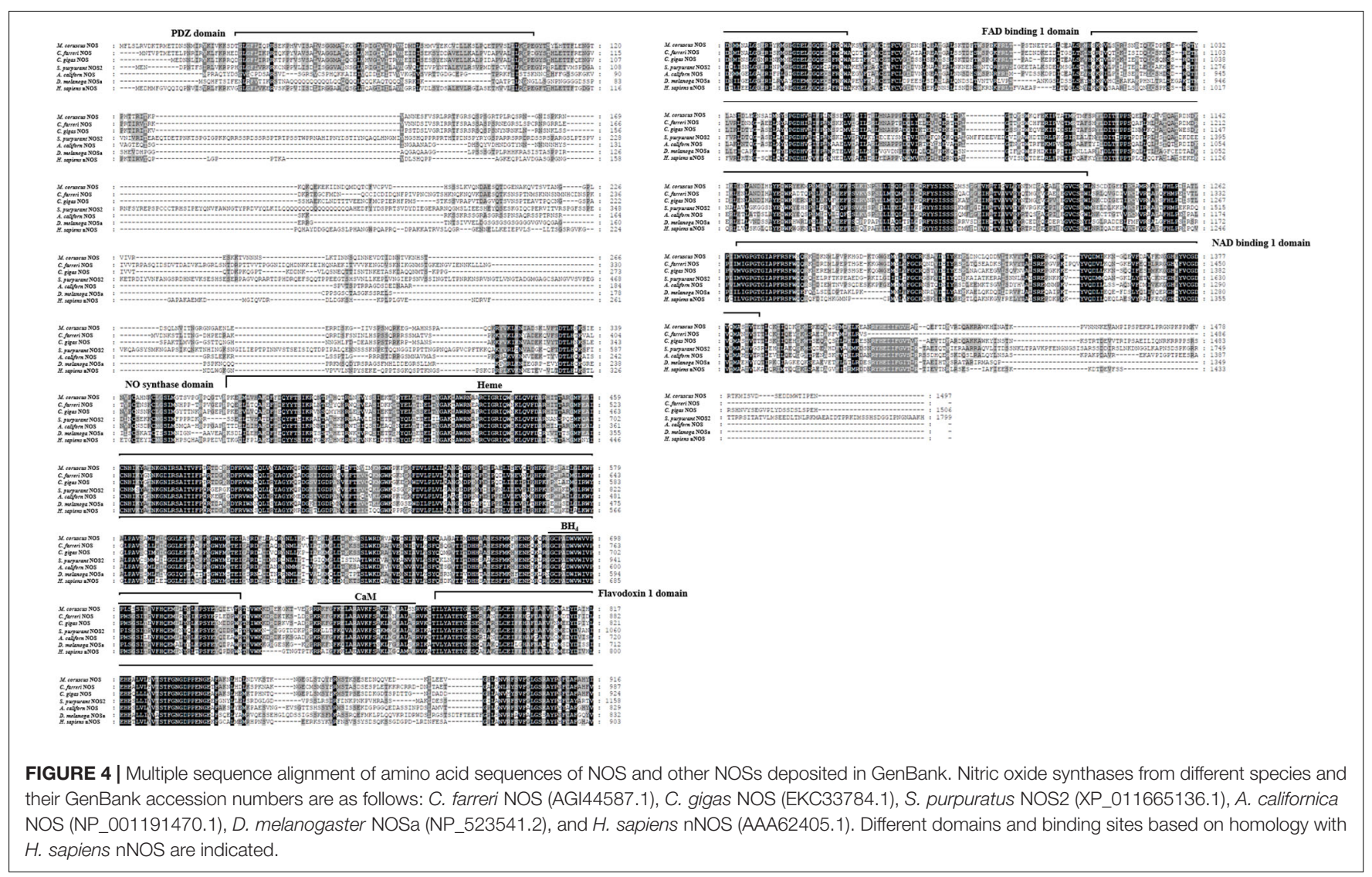

and a 481-bp 3' UTR (Figure 3). The putative polypeptide of 1497 amino acids has a predicted molecular mass of $169.1 \mathrm{kDa}$ and a theoretical pI of 8.14. The predicted protein has five signature domains; a PDZ domain spanning residues 30-105, an NOS domain spanning residues 367-729, a flavodoxin 1 domain spanning residues 778-947, an FAD-binding 1 domain spanning residues 1004-1234, and an NAD-binding 1 domain spanning residues 1266-1386. There are no predicted signal peptides or transmembrane domains. Also, five potential N-glycosylation sites (NXT) and a typical putative polyadenylation consensus sequence (AATAA) upstream from the poly(A) tail were also identified (Figure 3).

\section{Amino Acid Sequence and Phylogenetic Analyses of $M$. coruscus NOS}

The putative $M$. coruscus NOS protein shares high sequence identity with Chlamys farreri NOS (59\% identity, 93\% similarity), Crassostrea gigas NOS (62\% identity, $96 \%$ similarity), Strongylocentrotus purpuratus NOS (49\% identity, 89\% similarity), Aplysia californica NOS (60\% identity, 79\% similarity), Drosophila melanogaster NOS (50\% identity, $75 \%$ similarity), and Homo sapiens NOS (48\% identity, 94\% similarity). Multiple sequence alignment also revealed high sequence conservation with $M$. coruscus NOS and NOS proteins from other species, as well as with human neuronal NOS (nNOS), especially the PDZ, NOS, flavodoxin 1, FAD-binding 1, NAD-binding 1 domains, and the binding sites for heme, tetrahydrobiopterin $\left(\mathrm{BH}_{4}\right)$, and calmodulin (CaM; Figure 4). A phylogenetic tree was constructed using the ML method based on analysis of the amino acid sequences of $M$. coruscus NOS and its homologs from other species. The results showed that M. coruscus NOS initially clusters with NOS proteins from class Bivalvia and then with two NOS sequences from another mollusk (Figure 5). Invertebrate NOS sequences from the same species were clustered together, but in vertebrates, the same types of NOS in different species were clustered together initially (Figure 5).

\section{McNOS and HSP9O Genes Are Highly Expressed in Umbo Veliger Larvae and Expressed at Lower Levels in Other Developmental Stages}

To investigate the function of NOS in M. coruscus larval development and different larval stages, mRNA levels of McNOS and the chaperone HSP90 were determined. As shown in Figure 6, McNOS and HSP90 mRNAs were expressed at variable levels across all developmental stages. McNOS mRNA was expressed at a low level in trochophore and $\mathrm{D}$-shaped stages and was increased sharply in umbo veliger larvae. McNOS expression then decreased in pediveliger larvae and postlarvae stages, without significant differences between these two stages $(p<0.05)$, immediately and shortly after larval metamorphosis, respectively (Figure 6A). In contrast to McNOS, HSP90 was expressed most highly in umbo veliger larvae, but trochophore 


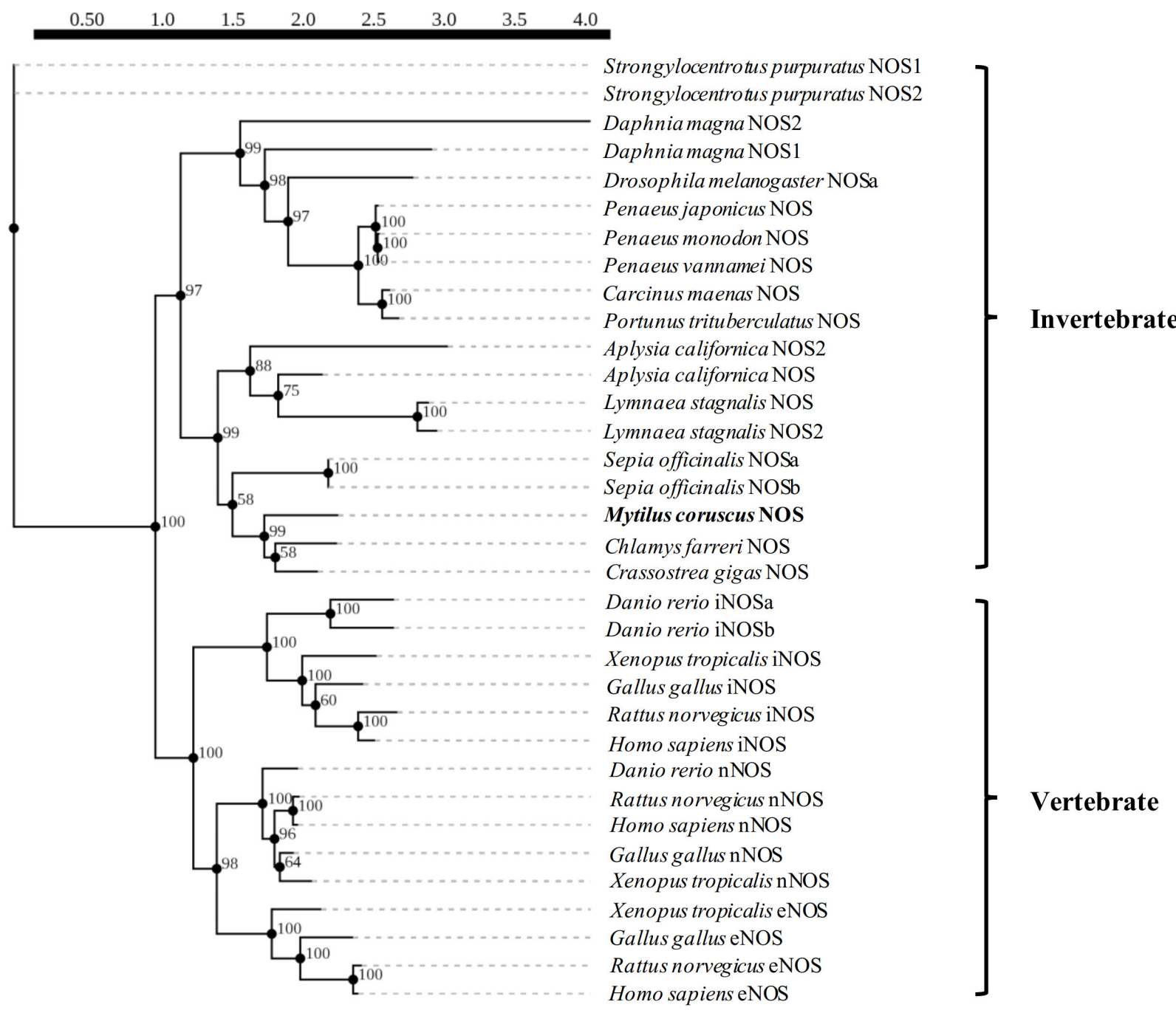

FIGURE 5 | Phylogenetic analysis of amino acid sequences of $M$. coruscus NOS and other invertebrate and vertebrate NOS proteins. The phylogenetic tree was constructed using the ML method with PhyML software. GenBank accession numbers of proteins are the same as those in Figure 5, accompanied by S. purpuratus NOS1 (XP_003729305.1), D. magna NOS2 (ACQ55299.1), D. magna NOS1 (ACQ55298.1), P. japonicus NOS (BAI67609.1), P. monodon NOS (ACJ54486.1), P. vannamei NOS (ADD63793.1), C. maenas NOS (ACY56317.1), P. trituberculatus NOS (AMV91694.1), A. californica NOS2 (AAK92211.3), L. stagnalis NOS (AAC17487.1), L. stagnalis NOS2 (AAW88577.1), S. officinalis NOSa (AAS93626.1), S. officinalis NOSb (AAS93627.1), D. rerio iNOSa (NP_001106973.1), D. rerio iNOSb (NP_001098407.1), D. rerio iNOSb (NP_001098407.1), D. rerio nNOS (NP_571735.1), X. tropicalis iNOS (XP_002935342.1), X. tropicalis nNOS (XP_002938130.2), X. tropicalis eNOS (ACV74251.1), G. gallus iNOS (NP_990292.1), G. gallus nNOS (XP_425296.2), G. gallus eNOS (AFD20677.1), R. norvegicus iNOS (AAC13747.1), R. norvegicus nNOS (AAA62405.1), Rattus norvegicus eNOS (NP_068610.1), H. sapiens iNOS (NP_000616.3), H. sapiens nNOS (NP_000616.3), and H. sapiens eNOS (NP_000594.2).

and pediveliger larvae exhibited the next highest levels, and expression was at a low level in D-veliger larvae and postlarvae (Figure 6B). HSP90 expression peaked in umbo veliger larvae and decreased continuously in the pediveliger larvae and postlarvae stage, consistent with McNOS expression (Figure 6B). Unlike McNOS, expression of HSP90 in pediveliger larvae and the postlarvae stage was significantly different $(p<0.05)$.

We also investigated the mRNA expression levels of $\mathrm{McNOS}$ and HSP90 in different tissues of adult mussels, specifically mantle, adductor muscle, gill, foot, digestive gland, and male and female gonads. The results indicated that both two genes were expressed at a high level in gill, gonad, and mantle
(Supplementary Figure S1), partially consistent with expected expression profiles.

\section{NOS Activity in M. coruscus Larvae at Different Developmental Stages}

Nitric oxide synthase protein levels and enzyme activity determine the amount of endogenous NO in larvae. To further investigate the relationship between $\mathrm{NO}$ and larval metamorphosis, the enzyme activity of NOS was measured in different larval developmental stages. NOS enzyme activity was highest in the D-veliger larvae (20\%), followed by the pediveliger 

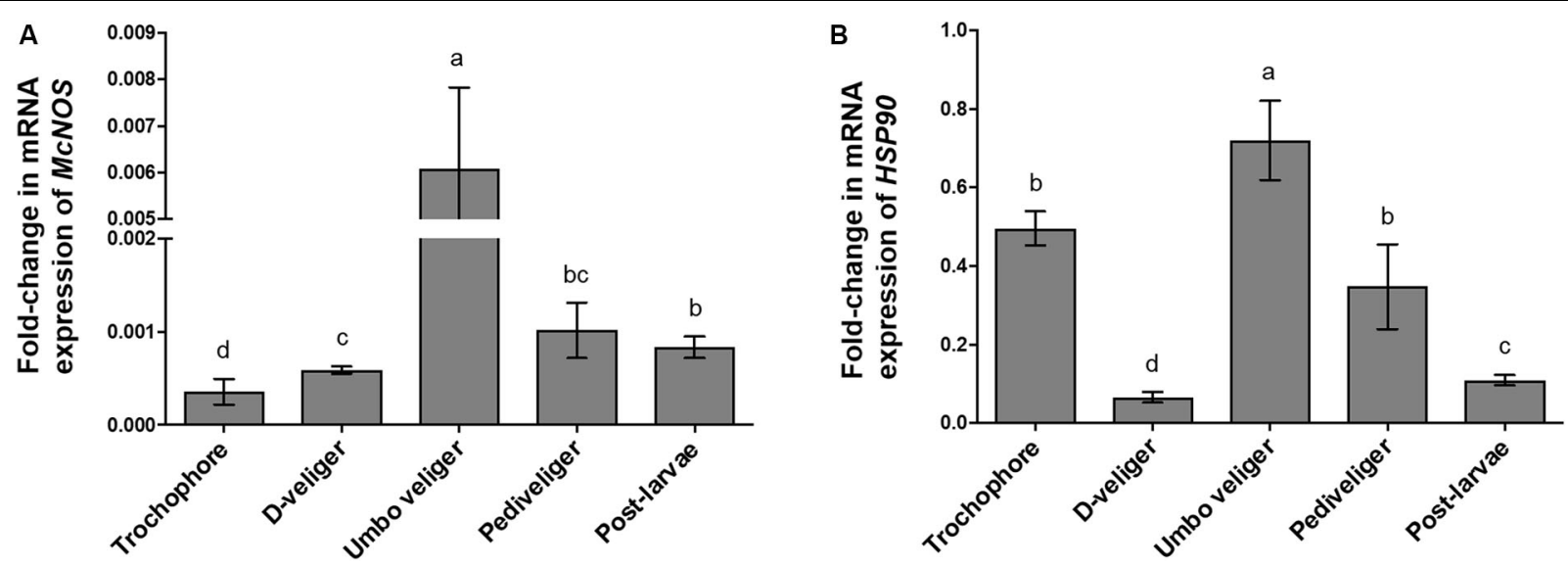

FIGURE 6 | Temporal expression of NOS mRNA during M. coruscus ontogenesis. (A) mRNA expression levels of McNOS in different developmental stages. (B) mRNA expression levels of HSP90 in different developmental stages. The EF-1 $\alpha$ gene was used as an internal control to normalize the relative mRNA levels of MCNOS and HSP90. Results are means $\pm \operatorname{SEM}(n=6)$, and bars with different letters are significantly different $(p<0.05)$.

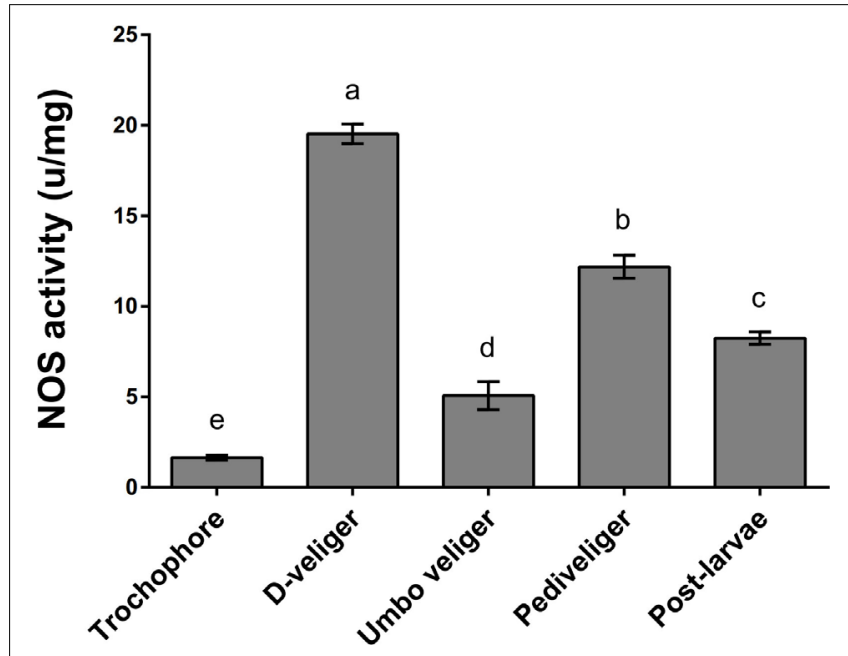

FIGURE 7 | Measurement of native NOS enzyme activity during different developmental stages of $M$. coruscus. Results are expressed as units of activity per milligram protein $(\mathrm{U} / \mathrm{mg})$. Values are means $\pm \operatorname{SEM}(n=5)$, and bars with different letters are significantly different $(p<0.05)$.

larvae $(12 \%)$, postlarvae $(8 \%)$, and umbo veliger larvae stages (5\%; Figure 7). The lowest NOS enzyme activity was observed in the trochophore stage (2\%; Figure 7$)$. These results are inconsistent with those for expression of McNOS and even display the opposite trend.

\section{DISCUSSION}

Since the biological function of NO was first discovered, NOmediated physiological responses have been studied in both vertebrates and invertebrates (Colasanti and Venturini, 1998; García-Cardeña et al., 1998; Bruckdorfer, 2005). Previous studies have reported that $\mathrm{NO}$ acts as a metamorphosis regulator in marine invertebrates (Froggett and Leise, 1999; Pechenik et al., 2007; Bishop et al., 2008; Romero et al., 2012; Ueda and Degnan, 2013, 2014). However, this regulatory role is still unknown in mussel. In the present study, we demonstrate that larval metamorphosis of $M$. coruscus is negatively regulated by NO. The results showed that NOS inhibitors increased the metamorphosis rate of mussel larvae, and this process was suppressed by an exogenous NO donor. To further investigate the role of NO in larval metamorphosis, we cloned the full-length cDNA of McNOS and measured the temporal expression of McNOS and HSP90 genes in different larval stages.

Studies have shown that NOS inhibitors can regulate the settlement and metamorphosis of invertebrate larvae through the NO signaling pathway (Bishop et al., 2001, 2008; Comes et al., 2007; Pechenik et al., 2007; Romero et al., 2012; Yang et al., 2018). For example, appropriate concentrations of AGH and SMIS can effectively induce the metamorphosis of Crepidula fornicata larvae (Pechenik et al., 2007); AGH, SMIS, and 7nitroindazole can induce metamorphosis of Capitella teleta larvae (Biggers et al., 2012), and L-NAME can induce abnormal development in Alderia willowi larvae (Romero et al., 2012). In the present study, four NOS inhibitors (AGH, 7-nitroindazole, L-NAME, and SMIS) were tested for their ability to induce metamorphosis in mussel larvae. The inhibitors AGH and L-NAME did significantly induce metamorphosis with dose dependence, indicating that endogenous NO is a facilitator of metamorphic induction in $M$. coruscus, and production of NO is related to NOS.

Importantly, the NO donors SNAP, L-arginine, and nitroprusside could inhibit larvae metamorphosis significantly in the absence of endogenous $\mathrm{NO}$, which indicates that exogenous NO can also suppress larval metamorphosis. In the ascidian $C$. intestinalis, studies have shown that NO regulates larval metamorphosis through ERK signaling (Castellano et al., 2014). In the bryozoan Bugula neritina, endogenous NO may regulate larval settlement through cGMP and p38MAPK signaling pathways (Yang et al., 2018). 
These results suggest that if these signal pathways also operate in mussels, exogenous NO may enter the cell interior directly and regulate metamorphosis through these pathways.

To date, NOS genes have been cloned from various mollusks including Lymnaea stagnalis (Korneev et al., 1998), Sepia officinalis (Scheinker et al., 2005), Terrestrial slug (Matsuo et al., 2008), Stramonita haemastoma (Cioni et al., 2012), H. asinina (Ueda and Degnan, 2014), and C. farreri (Jiang et al., 2013). Multiple sequence alignment of McNOS from $M$. coruscus and other species revealed high sequence similarity among NOS proteins from invertebrates to mammals, especially the PDZ, NOS, flavodoxin 1, FAD-binding 1, and NAD-binding 1 domains and the binding sites for heme, tetrahydrobiopterin $\left(\mathrm{BH}_{4}\right)$, and CaM. Furthermore, the PDZ domain also indicated the neuronal character of McNOS (Andreakis et al., 2011). Although invertebrate NOS genes appear to encode constitutive neuronal-like isoforms in terms of sequence similarity and protein structure, studies on the evolution of NOS have indicated that they are equally related to the three NOS genes in vertebrates (Andreakis et al., 2011). Our present phylogenetic analysis of invertebrate and vertebrate NOS sequences supports this conclusion. The results also showed that differences between NOS isoforms in the same species were less than those between the same isoforms in different species, which demonstrates fewer differences between paralogous NOS genes than between orthologous genes in invertebrates.

NOS gene expression levels in marine invertebrate larvae at different developmental stages can be used to speculate the role of NO in larval metamorphosis. In C. intestinalis, NOS expression was highest in the egg, moderate in early and middle larval stages, and increased sharply in late larvae (the stage prior to initiation of metamorphosis). Expression of NOS then decreases continuously in larvae during metamorphosis and in juvenile stages (Comes et al., 2007). As a negative regulator of tail resorption, high-level expression of NOS in late larvae indicates that NO must be maintained in the larval state until metamorphosis begins (Comes et al., 2007). When metamorphosis starts, expression of the NOS gene decreases immediately (Comes et al., 2007). However, in A. amphitrite, expression of NOS remains low in all larval stages, even prior to initiation of metamorphosis, suggesting that expression of NOS during the initial stages of metamorphosis is not conserved, even though NO inhibits metamorphosis in these species (Zhang et al., 2012). In contrast with $H$. momus and $H$. asinina, in which NO acts as an inducer of larval metamorphosis, NOS is expressed at a high level in larval and early postlarvae stages, consistent with its function as a positive regulator of metamorphosis (Ueda and Degnan, 2013, 2014). In the present s-tudy, expression of McNOS in M. coruscus was higher in umbo veliger larvae, but low in pediveliger and postlarvae stages, with no significant differences between these stages. This indicates a potential inhibitory function for $\mathrm{NO}$ in larval metamorphosis because metamorphosis is just beginning and just completed in pediveliger larval and postlarvae stages, respectively. Similar to C. intestinalis, NOS is highly expressed in umbo veliger larvae, further indicating that NO must be maintained in the larval state until metamorphosis is triggered.

As a molecular chaperone, the expression profile of HSP90 should be similar to that of NOS, as proven for H. momus and $H$. asinina (Ueda and Degnan, 2013, 2014). In the postlarvae stages of H. momus and H. asinina, HmHSP90 and HasHSP90 expression is increased initially then decreased as metamorphosis progresses, comparable to HmNOS and HasNOS expression (Ueda and Degnan, 2013, 2014). In the present study, HSP90 was expressed at high and low levels in the umbo veliger and postlarvae stages, and expression was significantly decreased from umbo veliger to postlarvae stages. This similarity in the expression profile of HSP90 and McNOS indicates potential functional synergism between these two molecules, and HSP90 also probably acts as a molecular chaperone for McNOS in $M$. coruscus. The significant difference in HSP90 expression between pediveliger and postlarvae stages suggests that HSP90 probably exhibits functional diversity in pediveliger larvae.

Nitric oxide synthase enzyme activity was investigated to further verify the relationship between $\mathrm{NO}$ and larval metamorphosis. The results showed that NOS activity was inconsistent with McNOS expression and even showed the opposite trend. This is probably because although expression of $M c N O S$ in umbo veliger larvae was higher than in other larval stages, enzyme activity was low, suggesting that NO is present at relatively low levels during each stage of larval development. However, this hypothesis requires experimental verification.

Studies in $H$. asinina have shown that the NOS gene is highly expressed in the anterior part of the larval foot (and the cephalic tentacle) in larvae, suggesting that NO modulates the metamorphic induction of $H$. asinina larvae via the larval foot, indicating that this tissue acts as a chemosensory structure to receive and process external metamorphosis cues (Ueda and Degnan, 2014). In C. farreri, NOS mRNA transcripts were detected in most embryos and larvae and constitutively expressed in all tissues, suggesting that the NO system may be involved in numerous physiological processes (Jiang et al., 2013). Moreover, a potential immune function was also inferred based on its higher expression in hemocytes after immune challenge (Hillyer and Estévez-Lao, 2010; Jiang et al., 2013). Tissue-specific expression of NOS indicates the potential functions of NO, whereas measurement of $\mathrm{NO}$ levels in tissues provides more direct functional evidence. In C. intestinalis, NO localization analysis in larvae showed a spatial correlation in the developmental process and tail regression. During development, the NOS expression moves rapidly from the anterior body to central nervous system, tail, and new forming juvenile digestive organs (Comes et al., 2007). In tail regression stage, NO localization displayed a strong signal at the tail extremity, where the apoptotic wave is initiated, then in different cellular layers of the tail, indicating the relationship between $\mathrm{NO}$ and apoptosis during metamorphosis (Comes et al., 2007). The results of the present study showed that the McNOS gene was expressed in all tissues of $M$. coruscus, similar to C. farreri (Jiang et al., 2013). High McNOS gene expression in the gill and digestive gland may suggest a potential immune function for NO because these tissues are crucial for host defenses in mussels. Expression levels of McNOS in 
gonads were lower, probably because the NO system is also involved in the regulation of gametic development or steroid production in mussels. Interestingly, high-level expression of McNOS in the foot and mantle was also observed in Ilyanassa obsolete and in the anterior foot of $H$. asinina larvae, which may contain sensory cells (Thavaradhara and Leise, 2001; Ueda and Degnan, 2014). Therefore, in larval metamorphosis in mussels, NO may act as a signaling transmitter that decodes environmentally derived cues to induce morphogenetic signaling pathways via the sensory nervous system.

\section{CONCLUSION}

In summary, the results of integrated metamorphosis assays following pharmacological treatments, and gene expression analysis of McNOS and HSP90, indicate that NO acts as a suppressor of $M$. coruscus metamorphosis, regardless of whether $\mathrm{NO}$ is endogenous or exogenous. We also showed that expression of HSP90 was comparable to McNOS; both were expressed at low levels in the postlarvae stage, indicating potential functional synergism between these two molecules. In addition, NOS enzyme activity was inconsistent with McNOS expression, but the underlying mechanism remains to be determined.

\section{DATA AVAILABILITY STATEMENT}

The datasets generated for this study can be found in the GenBank ID: MN153299.

\section{REFERENCES}

Andreakis, N., Aniello, S. D., Albalat, R., Patti, F. P., Garciafernandez, J., and Procaccini, G. (2011). Evolution of the nitric oxide synthase family in metazoans. Mol. Biol. Evol. 28, 163-179. doi: 10.1093/molbev/m sq179

Beiras, R., and Widdows, J. (1995). Induction of metamorphosis in larvae of the oyster Crassostrea gigas using neuroactive compounds. Mar. Biol. 123, 327-334. doi: $10.1007 /$ bf00353624

Bender, A. T., Silverstein, A. M., Demady, D. R., Kanelakis, K. C., Noguchi, S., Pratt, W. B., et al. (1999). Neuronal nitric-oxide synthase is regulated by the Hsp90-based chaperone system in vivo. J. Biol. Chem. 274, 1472-1478. doi: 10.1074/jbc.274.3.1472

Biggers, W. J., Pires, A., Pechenik, J. A., Johns, E., Patel, P., Polson, T., et al. (2012). Inhibitors of nitric oxide synthase induce larval settlement and metamorphosis of the polychaete annelid Capitella teleta. Invertebr. Reprod. Dev. 56, 1-13. doi: 10.1080/07924259.2011.588006

Bishop, C. D., Bates, W. R., and Brandhorst, B. P. (2001). Regulation of metamorphosis in ascidians involves NO/cGMP signaling and HSP90. J. Exp. Zool. 289, 374-384. doi: 10.1002/jez.1019

Bishop, C. D., and Brandhorst, B. P. (2001). NO/cGMP signaling and HSP90 activity represses metamorphosis in the sea urchin Lytechinus pictus. Biol. Bull. 201, 394-404. doi: 10.2307/1543617

Bishop, C. D., Pires, A., Norby, S. W., Boudko, D., Moroz, L. L., and Hadfield, M. G. (2008). Analysis of nitric oxide-cyclic guanosine monophosphate signaling during metamorphosis of the nudibranch Phestilla sibogae Bergh (Gastropoda: Opisthobranchia). Evol. Dev. 10, 288-299. doi: 10.1111/j.1525-142X.2008.0 0238.x

Borkovich, K. A., Farrelly, F. W., Finkelstein, D. B., Taulien, J., and Lindquist, S. (1989). Hsp82 is an essential protein that is required in higher concentrations

\section{AUTHOR CONTRIBUTIONS}

J-LY and XL designed the experiments. Y-TZ, YZ, and Y-ZL performed the experiments. Y-TZ, J-LY, and XL analyzed the data. Y-TZ, Y-FL, AY, and KO critically reviewed the data and wrote the manuscript. All authors read and approved the manuscript.

\section{FUNDING}

This work was supported by the Shanghai Sailing Program (19YF1419500), the National Natural Science Foundation of China (Nos. 41606147, 31101885, and 41476131), and Shanghai University First-class Disciplines Project of Fisheries.

\section{SUPPLEMENTARY MATERIAL}

The Supplementary Material for this article can be found online at: https://www.frontiersin.org/articles/10.3389/fmars. 2020.00356/full\#supplementary-material

FIGURE S1 | Tissue transcriptional analysis of $M$. coruscus NOS and HSP9O mRNA. (a) Levels of McNOS mRNA in different tissues. (b) Levels of HSP9O mRNA in different tissues. Expression of MCNOS and HSP90 transcripts in seven tissues from five mussels was quantified by quantitative real-time PCR (RT-qPCR). The EF-1 $\alpha$ gene was used an internal control to normalize the relative mRNA levels of NOS. Results are means $\pm \operatorname{SEM}(n=6)$, and bars with different letters are significantly different $(p<0.05)$.

for growth of cells at higher temperatures. Mol. Cell. Biol. 9, 3919-3930. doi: 10.1128/MCB.9.9.3919

Bruckdorfer, R. (2005). The basics about nitric oxide. Mol. Aspects. Med. 26, 3-31. doi: 10.1016/j.mam.2004.09.002

Castellano, I., Ercolesi, E., and Palumbo, A. (2014). Nitric oxide affects ERK signaling through down-regulation of MAP Kinase phosphatase levels during larval development of the ascidian Ciona intestinalis. PLoS One 9:e102907. doi: 10.1371/journal.pone.0102907

Cioni, C., Di Patti, M. C. B., Venturini, G., Modica, M. V., Scarpa, F., Oliverio, M., et al. (2012). Cellular, biochemical, and molecular characterization of nitric oxide synthase expressed in the nervous system of the prosobranch Stramonita haemastoma (Gastropoda, Neogastropoda). J. Comp. Neurol. 520, 364-383. doi: $10.1002 /$ cne.22729

Colasanti, M., and Venturini, G. (1998). Nitric oxide in invertebrates. Mol. Neurobiol. 17, 157-174.

Comes, S., Locascio, A., Silvestre, F., d'Ischia, M., Russo, G. L., Tosti, E., et al. (2007). Regulatory roles of nitric oxide during larval development and metamorphosis in Ciona intestinalis. Dev. Biol. 306, 772-784. doi: 10.1016/j. ydbio.2007.04.016

Ercolesi, E., Tedeschi, G., Fiore, G., Negri, A., Maffioli, E., d'Ischia, M., et al. (2012). Protein nitration as footprint of oxidative stress-related nitric oxide signaling pathways in developing Ciona intestinalis. Nitric Oxide 27, 18-24. doi: 10.1016/j.niox.2012.03.012

Froggett, S. J., and Leise, E. M. (1999). Metamorphosis in the marine snail Ilyanassa obsoleta. Yes or NO? Biol. Bull. 196, 57-62. doi: 10.2307/1543167

García-Cardeña, G., Fan, R., Shah, V., Sorrentino, R., Cirino, G., Papapetropoulos, A., et al. (1998). Dynamic activation of endothelial nitric oxide synthase by Hsp90. Nature 392, 821-824. doi: 10.1038/33934

García-Lavandeira, M., Silva, A., Abad, M., Pazos, A. J., Sánchez, J. L., and PérezParallé, M. L. (2005). Effects of GABA and epinephrine on the settlement and 
metamorphosis of the larvae of four species of bivalve molluscs. J. Exp. Mar. Biol. Ecol. 316, 149-156. doi: 10.1016/j.jembe.2004.10.011

Grant, M. N., Meritt, D. W., and Kimmel, D. G. (2013). Chemical induction of settlement behavior in larvae of the eastern oyster Crassostrea virginica (Gmelin). Aquaculture 402-403, 84-91. doi: 10.1016/j.aquaculture.2013.03.031

Grossi, L., and D'Angelo, S. (2005). Sodium nitroprusside: mechanism of NO release mediated by sulfhydryl-containing molecules. J. Med. Chem. 48, 26222626. doi: $10.1021 / \mathrm{jm} 049857 \mathrm{n}$

Hadfield, M. G., Carpizo-Ituarte, E. J., del Carmen, K., and Nedved, B. T. (2001). Metamorphic competence, a major adaptive convergence in marine invertebrate larvae. Am. Zool. 41, 1123-1131. doi: 10.1093/icb/41.5.1123

Hadfield, M. G., Meleshkevitch, E. A., and Boudko, D. Y. (2000). The apical sensory organ of a gastropod veliger is a receptor for settlement cues. Biol. Bull. 198, 67-76. doi: $10.2307 / 1542804$

Hillyer, J. F., and Estévez-Lao, T. Y. (2010). Nitric oxide is an essential component of the hemocyte-mediated mosquito immune response against bacteria. Dev. Comp. Immunol. 34, 141-149. doi: 10.1016/j.dci.2009.08.014

Hong, J. K., Yun, B. W., Kang, J. G., Raja, M. U., Kwon, E., Sorhagen, K., et al. (2008). Nitric oxide function and signalling in plant disease resistance. J. Exp. Bot. 59, 147-154. doi: 10.1093/jxb/erm244

Jiang, Q., Zhou, Z., Wang, L., Wang, L., Yue, F., Wang, J., et al. (2013). A scallop nitric oxide synthase (NOS) with structure similar to neuronal NOS and its involvement in the immune defense. PLoS One 8:e69158. doi: 10.1371/journal. pone. 0069158

Joyce, A., and Vogeler, S. (2018). Molluscan bivalve settlement and metamorphosis: neuroendocrine inducers and morphogenetic responses. Aquaculture 487, $64-$ 82. doi: 10.1016/j.aquaculture.2018.01.002

Korneev, S. A., Piper, M. R., Picot, J., Phillips, R., Korneeva, E. I., and O'Shea, M. (1998). Molecular characterization of NOS in a mollusc: expression in a giant modulatory neuron. J. Neurobiol. 35, 65-76. doi: 10.1002/(sici)10974695(199804)35:1

Lindquist, S., and Craig, E. A. (1988). The heat-shock proteins. Annu. Rev. Genet. 22, 631-677. doi: 10.1146/annurev.ge.22.120188.003215

Livak, K. J., and Schmittgen, T. D. (2001). Analysis of relative gene expression data using real-time quantitative PCR and the 2- $\Delta \Delta$ CT method. Methods 25, 402-408. doi: 10.1006/meth.2001.1262

Lucas, K. A., Pitari, G. M., Kazerounian, S., Ruiz-Stewart, I., Park, J., Schulz, S., et al. (2000). Guanylyl cyclases and signaling by cyclic GMP. Pharmacol. Rev. $52,375-414$.

Matsuo, R., Misawa, K., and Ito, E. (2008). Genomic structure of nitric oxide synthase in the terrestrial slug is highly conserved. Gene 415, 74-81. doi: 10. 1016/j.gene.2008.02.021

Mesías-Gansbiller, C., Silva, A., Maneiro, V., Pazos, A., Sánchez, J. L., and PérezParallé, M. L. (2013). Effects of chemical cues on larval settlement of the flat oyster (Ostrea edulis L.): a hatchery approach. Aquaculture 376-379, 85-89. doi: 10.1016/j.aquaculture.2012.11.022

Palumbo, A. (2005). Nitric oxide in marine invertebrates: a comparative perspective. Comp. Biochem. Physiol. A Mol. Integr. Physiol. 142, 241-248. doi: 10.1016/j.cbpb.2005.05.043

Pechenik, J. A., Cochrane, D. E., Li, W., West, E. T., Pires, A., and Leppo, M. (2007). Nitric oxide inhibits metamorphosis in larvae of Crepidula fornicata, the Slippershell snail. Biol. Bull. 213, 160-171. doi: 10.2307/25066632

Qian, P. Y. (1999). Larval settlement of polychaetes. Hydrobiologia 402, 239-253. doi: 10.1023/a:1003704928668

Rodríguez, S. R., Ojeda, F. P., and Inestrosa, N. C. (1993). Settlement of benthic marine invertebrates. Mar. Ecol. Prog. Ser. 97, 193-207. doi: 10.3354/ meps097193

Romero, M. R., Phuong, M. A., Bishop, C., and Krug, P. J. (2012). Nitric oxide signaling differentially affects habitat choice by two larval morphs of the sea slug Alderia willowi: mechanistic insight into evolutionary transitions in dispersal strategies. J. Exp. Biol. 216, 1114-1125. doi: 10.1242/jeb.080747
Scheinker, V., Fiore, G., Di Cristo, C., Di Cosmo, A., d'Ischia, M., Enikolopov, G., et al. (2005). Nitric oxide synthase in the nervous system and ink gland of the cuttlefish Sepia officinalis: molecular cloning and expression. Biochem. Biophys. Res. Commun. 338, 1204-1215. doi: 10.1016/j.bbrc.2005.10.069

Strathmann, R. R. (1993). Hypotheses on the origins of marine larvae. Annu. Rev. Ecol. Syst. 24, 89-117. doi: 10.1146/annurev.es.24.110193.000513

Stuehr, D. J. (2004). Enzymes of the l-arginine to nitric oxide pathway. J. Nutr. 134, 2748S-2751S. doi: 10.1093/jn/134.10.2748S

Teh, C. P., Zulfigar, Y., and Tan, S. H. (2012). Epinephrine and l-DOPA promote larval settlement and metamorphosis of the tropical oyster, Crassostrea iredalei (Faustino, 1932): an oyster hatchery perspective. Aquaculture 338-341, 260-263. doi: 10.1016/j.aquaculture.2012.01.014

Thavaradhara, K., and Leise, E. M. (2001). Localization of nitric oxide synthaselike immunoreactivity in the developing nervous system of the snail Ilyanassa obsoleta. J. Neurocytol. 30, 449-456. doi: 10.1023/a:1015669112986

Ueda, N., and Degnan, S. M. (2013). Nitric oxide acts as a positive regulator to induce metamorphosis of the ascidian Herdmania momus. PLoS One 8:e72797. doi: 10.1371/journal.pone.0072797

Ueda, N., and Degnan, S. M. (2014). Nitric oxide is not a negative regulator of metamorphic induction in the abalone Haliotis asinina. Front. Mar. Sci. 1:21. doi: 10.3389/fmars.2014.00021

Wang, C., Bao, W. Y., Gu, Z. Q., Li, Y. F., Liang, X., Ling, Y., et al. (2012). Larval settlement and metamorphosis of the mussel Mytilus coruscus in response to natural biofilms. Biofouling 28, 249-256. doi: 10.1080/08927014.2012.6 71303

Yang, J. L., Satuito, C. G., Bao, W. Y., and Kitamura, H. (2008). Induction of metamorphosis of pediveliger larvae of the mussel Mytilus galloprovincialis Lamarck, 1819 using neuroactive compounds, $\mathrm{KCl}, \mathrm{NH} 4 \mathrm{Cl}$ and organic solvents. Biofouling 24, 461-470. doi: 10.1080/08927010802340309

Yang, J. L., Shen, P. J., Liang, X., Li, Y. F., Bao, W. Y., and Li, J. L. (2013). Larval settlement and metamorphosis of the mussel in response to monospecific bacterial biofilms. Biofouling 29, 247-259. doi: 10.1080/08927014.2013.764412

Yang, X. X., Wong, Y. H., Zhang, Y., Zhang, G., and Qian, P. Y. (2018). Exploring the regulatory role of nitric oxide (NO) and the NO-p38MAPK/cGMP pathway in larval settlement of the bryozoan Bugula neritina. Biofouling 34, 545-556. doi: 10.1080/08927014.2018.1470240

Yoshida, M., and Xia, Y. (2003). Heat shock protein 90 as an endogenous protein enhancer of inducible nitric-oxide synthase. J. Biol. Chem. 278, 36953-36958. doi: 10.1074/jbc.M305214200

Young, J. C., Moarefi, I., and Hartl, F. U. (2001). ). Hsp90: a specialized but essential protein-folding tool. J. Cell Biol. 154, 267-273. doi: 10.1083/jcb.200104079

Zhang, G., Wong, Y. H., Zhang, Y., He, L. S., Xu, Y., and Qian, P. Y. (2015). Nitric oxide inhibits larval settlement in Amphibalanus amphitrite cyprids by repressing muscle locomotion and molting. Proteomics 15, 3854-3864. doi: 10.1002/pmic.201500112

Zhang, Y., He, L. S., Zhang, G., Xu, Y., Lee, O. O., Matsumura, K., et al. (2012). The regulatory role of the NO/cGMP signal transduction cascade during larval attachment and metamorphosis of the barnacle Balanus (=Amphibalanus) amphitrite. J. Exp. Biol. 215, 3813-3822. doi: 10.1242/jeb.070235

Conflict of Interest: The authors declare that the research was conducted in the absence of any commercial or financial relationships that could be construed as a potential conflict of interest.

Copyright $\odot 2020 \mathrm{Zhu}$, Zhang, Liu, Li, Yoshida, Osatomi, Yang and Liang. This is an open-access article distributed under the terms of the Creative Commons Attribution License (CC BY). The use, distribution or reproduction in other forums is permitted, provided the original author(s) and the copyright owner(s) are credited and that the original publication in this journal is cited, in accordance with accepted academic practice. No use, distribution or reproduction is permitted which does not comply with these terms. 